\title{
THE FINANCIAL PLANNING AND FINANCIAL \\ LITERACY OF EX-MALAYSIA INDONESIAN \\ MIGRANT WORKERS ${ }^{1}$
}

\section{Rayenda Khresna Brahmana, Ritzky Karina Brahmana*}

\begin{abstract}
Indonesian migrant workers (IMW) face life difficulties after returning back to Indonesia. This is a contrary condition considering their contribution to their home family in Indonesia while working abroad. Literature mentions that their financial planning is the root of the poverty of ex-IMW. Therefore, this research adopts literacy theory to explain this phenomenon. This research conducted a survey among 548 ex-IMW and measures their financial literacy and financial planning. This research also maps their asset ownership to examine the relationship between financial literacy and asset ownership. Overall, this research documents that financial literacy contributes statistically significantly and positively to financial planning. Furthermore, this research shows that asset ownership is closely related to financial literacy. In a nutshell, this research concludes that it is important for migrant workers to have good knowledge of financial issues, because having good financial literacy helps the migrant workers to plan their finance and budget much better, thereby helping them to avoid the poverty trap. Therefore, policymakers such as migrant worker authorities and/or Indonesian embassies abroad have to institute financial education programmes for migrant workers before they return to Indonesia.
\end{abstract}

Keywords: Financial literacy, financial planning, migrant workers, Indonesia JEL Classification: D91, D80, G11

\section{Introduction}

There are about 2 million Indonesian migrant workers (hereafter, IMW) working in Malaysia currently; the biggest among the migrant workers' destination countries. The national authority for migrant worker placement and protection of Indonesians (hereafter, the migrant bureau) reported that the remittances from those workers to Indonesia reached USD 7.4 billion in 2013; the largest among the migrant workers' destination countries. This implies that IMW are important for Indonesia's economy.

The main reason for IMWs' work in Malaysia is indeed for having a better life. The migrant bureau reports that one IMW might save five of his/her relatives in their home village. Nevertheless, the life after returning to Indonesia is a different story for most migrant workers, where most of ex-IMW face their lives in poverty again. This leads to intriguing questions: What have they done with their money? What has happened to their remittances?

1 Authors acknowledge the financial support from the University Malaysia Sarawak for Small Grant Scheme F01(s144)/1174/2014(09).

* University Malaysia Sarawak, Kuching, Faculty of Economics and Business (brkhresna@unimas.my); Petra Christian University, Surabaya, Indonesia, Faculty of Economics (kikybrahmana@gmail.com). 
The major contributor to this unchanged income status for most IMWs is their financial planning. The migrant bureau reports that IMW tend to transfer a large portion of their money to Indonesia, and afterwards spend the rest in Malaysia. This is consistent with the findings of Raharto [2007], who found that female IMW had transferred their money back significantly in the hope that the family will either use it or save it, while they spend the rest.

To explain this phenomenon, this study uses literacy theory. Literacy theory describes how people learn about the world and how people can participate in society [McEneaney, 2006]. This theory was then adopted and reintroduced by Mitchell et al. [2000] in constructing another postulate called financial literacy theory, describing that a financially illiterate person tends to make poor economic decisions. There are many research papers in developed markets that have confirmed the link between financial literacy and decision making, such as Hastings and Tejeda-Ashton [2008], Servon and Kaestner [2008], Lusardi et al. [2010], Fornero and Moticone [2011], and van Rooij et al. [2012].

Prior studies show that financial planning is closely related to well-being [Lusardi \& Mitchell, 2007a, 2007b; Hana \& Lindamood, 2010; van Rooij et al., 2011]. This implies that those who have good management in their financial planning would lead a better resulting life. Yet little is known about why people fail to plan for retirement after being a migrant worker, and how planning as well as information shape retirement saving decisions.

Relating it back to the Indonesian context, those financial literacy research papers are tally with prior studies. For instance, Turner et al. [2009] address the fact that the Indonesian government has not optimized their HRM system, which would lead to decreasing human development index and inefficient governance. Lipsey and Sjoholm [2004] address the fact that education is one of the main sources of low-pay labour in Indonesian manufacturing companies. There are also findings of Booth [1999], who argues that the Indonesian government has not renovated their educational system, leading to retarded economic growth.

This paper explores the hypothesis that poor planning may be a primary result of financial illiteracy. That is, the Malaysian IMW who still live in poor conditions do so mostly due to their unawareness of fundamental economic concepts driving economic well-being during their working period. This study addresses the question of how IMW earn their money but yet fail in their economic life. There are few studies on migrant workers' understanding of financial planning [Dustmann, 1997; Zarate-Hoyos, 2004; De Haas, 2005], but far fewer on the Indonesian context, especially those who have just come back to their home country. While there are numerous formal economic theories for financial planning and well-being [e.g., Hamilton \& Moses, 1973; Kumar, 1984; Carino \& Ziemba, 1998], this paper embodies social economic research on explaining this phenomenon. This implies that this research aims to enrich the body of knowledge on financial planning and poverty from the point of view of sociology.

This study may help the Indonesian government in core-issue mapping of the ex-IMW's poverty. Our results surmise the importance of financial literacy for IMW's financial planning, and this may lead the Indonesian government to develop communication and education programmes related to financial literacy for them. Furthermore, the findings might help the Indonesian government to impose a new policy that might help the wellbeing of IMWs. 
The rest of the paper is organized as follows. In the next section, theoretical background is briefly reviewed. Section 2 describes the data, sample selection criteria, and preliminary analysis. Section 3 discusses the estimation and the significance of results methodology. Last section presents the conclusion and implications of the research.

\section{Theoretical background}

Why have many ex-Indonesian migrant workers (IMW) failed to enhance their lives after their arrival from abroad? How can an ex-IMW fail financially? Is it related to their financial planning? This section briefly reviews the theoretical background of migrant workers, financial planning and financial literacy, and discusses the relationship among them. This short review sets the conceptual framework for the specification of the empirical models tested thereafter.

Studies of migrant worker consumption behaviour show a rational utility relationship between income, savings, and consumption. Prior research, such as Adams [1991], Dustmann [1997], and De Haas [2005] addresses the utility flow of savings and consumption from the host country to the home country. It is inconclusive whether their returning to the home country might lead them to a better life. Dustmann [1997] shows that an increase in wages of migrant workers will not increase their savings. Their consumption behaviour from the working country is brought to their life in their home country. This is not to mention that their consumption behaviour in their home country is also influenced by their pride [Toth, 1991; Ishi, 2003]. This circumstance might worsen their actual life and trap them back in their previous life situation: living in poverty.

Some might blame the lack of migrant workers' financial planning on this matter [e.g., Puri \& Ritzema, 1999; Weekey, 2004; Datta, 2009; Seshan \& Yang, 2012]. Puri and Ritzema [1999] focus on how incentive schemes and imposing better policy of remittances might help not only the country, but also the migrant workers. They show that there is a lack of business counselling and training for migrant workers, which might harm their future life after returning home. Furthermore, they also emphasize the needs of entrepreneurship development for migrant workers to enhance their life. Weekley [2004] comes up with a similar conclusion. She discusses the need for economic reintegration by including training in savings and investment for migrants. This issue arises as there is an argument that migrant workers face difficulties after returning home as the result of bad financial planning. Datta [2009] explores the everyday financial practices and lives of low-paid migrant workers: the strategies which they devise in order to cope with financial exclusion, as well as focusing specifically on self-exclusion as a strategy which signifies a particular understanding and management of risk. He found out the interesting facts that migrant workers tend to not have good financial planning. Additionally, Seshan and Yang [2012] examine financial education of migrant workers in an experimental way. They examine impacts on financial decision-making of the migrant workers, migrants' attempts to influence the financial decision-making of their wives in the home country, migrant beliefs about their wives' behaviour, and the wives' actual behaviour. Surprisingly, they found that financial literacy interventions have a real potential to change migrants' financial behaviour.

Relating the impact of financial planning to financial literacy theory is indeed an interesting breakthrough for economic development. In financial literacy theory, it is 
shown how a highly financially literate person assists others in better economic planning. For instance, Lusardi and Mitchell [2007a] show that baby boomers with good financial literacy tend to have better financial planning, which helps them to increase their wealth. Lusardi and Mitchell [2007b] also show that lack of planning has important consequences for saving and portfolio choice: those who do not plan tend to accumulate far less wealth than those who plan, and non-planners are also less likely to invest in stocks and taxfavoured assets. They address financial literacy as the main source of this circumstance. Lusardi and Tufano [2009] surmise that over-indebtedness and its debt trap for households is due to lack of financial knowledge. Guiso and Jappelli [2008] conclude that good portfolio diversification relates to financial literacy. A person who has better financial literacy tends to have better portfolio performance. Additionally, Jappelli and Padula [2013] document a significant contribution of financial literacy to saving decisions that lead to better asset accumulation.

Study of impacts of literacy theory on financial planning is widely conducted in developed markets. An example is the paper by Beal and Delpachitra [2003], which documents the role of financial literacy in the planning of Australian university students. Sekita [2011] finds a significant relationship between financial literacy and retirement planning in Japan. Fornero and Monticone [2011] show a relationship between financial literacy and pension plan participation in Italy. Klapper and Panos [2011] relate financial literacy and retirement planning in Russia. Almenberg and Save-Soderberg [2011] document the role of financial literacy on financial planning in Sweden. There is also the research of van Rooij et al. [2011], which documents the role of financial literacy in financial planning in the Netherlands. In the German context, Bucher-Koenen and Lusardi [2011] show a significant association between financial literacy and financial planning. However, it is rare to find a research paper about financial literacy and financial planning in emerging markets, such as Indonesia. There is little research relating financial literacy and returning migrant workers' financial planning. This is the gap that this paper aims to bridge.

This brief review suggests that both theoretical prediction and empirical evidence converge to emphasize the interesting behaviour of ex-IMW, as well as the important role of financial literacy through financial planning in well-being of ex-IMWs. In this paper, we propose a test of these two hypotheses on the case of ex-IMWs from Malaysia, adopting literacy theory and complementary empirical approaches that are detailed below.

\section{Data and methodology}

\section{Data}

Unlike previous research into financial literacy, we conducted a survey study by distributing questionnaires instead of using National Health Survey (NHS) or other secondary data. There are two reasons for this. First, there is the methodological limitation of using NHS instead of an original survey, especially if we target ex-IMW as the sample. Second, there is no such NHS study in Indonesia. We distributed and collected 548 questionnaires over the period of August to October 2015 by using the snowballing sampling method. The sample covers ex-IMW from Malaysia. Before that, we did a focus group discussion to develop our questionnaire. 


\section{Method}

The basic economic formulation is used to estimate savings/consumption decisions under the conjecture that consumers are rational in their utility function of consumption over their lifetimes. The consumer has a lifetime expected utility, where the expected value of the sum period utility $U\left(C_{j}\right)$ discounted by $\beta$ to the present, multiplied by the probability of survival $p_{j}$ from the migrant worker's current age $j$ to the oldest possible lifetime $D$. The function is as follows:

$$
E\left[\sum_{j=1}^{D} \beta^{j-s} U\left(C_{j}\right)\right] .
$$

The migrant worker's assets and consumption $\left(a_{j}\right.$ and $\left.c_{j}\right)$ are driven endogenously by maximizing this function subject to an intertemporal budget constraint. Thus, $c_{j}$ represents per period consumption, $y_{j}$ is labour earnings, $a_{j}$ represents the households' returns on assets, and SS and PP represent their current aggregate of wealth:

and

$$
y_{j}=e_{j}+r a_{j}, j \in\{S, \ldots, R-1\}
$$

$$
y_{j}=S S_{j}(R)+P P_{j}(R)+r a_{j}, j \in[R, \ldots, D] .
$$

Furthermore, consumption from income, assets, and benefits is set so that:

$$
\begin{aligned}
& c_{j}+a_{j+1}=y_{j}+a_{j}, j \in[S, \ldots, R-1] \text { before returning }(\mathrm{R}), \text { and } \\
& c_{j}+a_{j+1}=y_{j}+a_{j}, j \in[S, \ldots, D] \text { after returning home. }
\end{aligned}
$$

In a simple way, the economic model estimates that migrant workers hold expectations regarding prospective survival probabilities, discount rates, investment returns, gross and net earnings, other assets, and inflation. Furthermore, this model explains that migrant workers use that information to formulate and execute optimal consumption/savings plans. This formulation explains that migrant workers require substantial financial literacy to optimize their consumption-savings link.

This research is interesting because it aims to investigate whether migrant workers succeed or fail in optimizing their consumption/savings utility, which is closely related to the knowledge of and the capability to plan and implement these complex planning tasks. This subject is particularly important in view of the fact that returning migrant workers are increasingly being given responsibility to save, manage their assets, and draw down their retirement assets in the defined contribution pension environment. Accordingly, what is critically needed is new information permitting analysts to investigate the links between financial literacy, the sources of information that households rely on for their economic decision-making, and planning.

This research aims to estimate this relationship using a baseline model such as:

$$
\text { planning }=\alpha_{i}+\beta_{1} \text { Gender }_{i}+\beta_{2} \text { Interest }_{i}+\beta_{3} \text { Inflation }_{i}+\beta_{4} \text { Investment }_{i}+\varepsilon_{i} .
$$

The Gender is the control variable; it 1 if woman, and 0 if else. Interest is the migrant worker's literacy about interest rate. Inflation is the migrant worker's literacy about inflation. Investment is the migrant worker's literacy about investment. 
To measure the financial literacy, this research adopted the question of financial literacy of Lusardi and Mitchell [2007a] and Lusardi et al. [2010]. The questions are as follows:

1) Suppose you had Rp 10.000.000 in a savings account and the interest rate was $10 \%$ per year. After 5 years, how much do you think you would have in the account if you left the money to grow: more than \$11million, exactly \$11million, less than \$11million?

2) Imagine that the interest rate on your savings account was $5 \%$ per year and inflation was $7 \%$ per year. After 1 year, would you be able to buy more than, exactly the same as, or less than today with the money in this account?

3) Which of the following statements do you think is better? "Having one basket with 300 eggs or having 5 baskets with 60 eggs?"

The first question is referred to as "Interest", and the second question is referred to as "Inflation". The two questions evaluate whether migrant workers display knowledge of fundamental economic concepts for saving decisions as well as possessing competence of basic financial numeracy. The third question is "Investment". The purpose of the third question is to evaluate respondents' knowledge of investment decisions.

The model also evaluates the respondents' financial planning by adopting questions from the Retirement Confidence Survey and questionnaires developed by TIAA-CREF and later developed and modified by Lusardi and Mitchell [2007b]. The assessment is as follows.
4) Have you ever tried to figure out how much your household would need to save for retirement? Yes or No.
5) Have you developed a plan for retirement saving? Yes, More or Less, No.
6) How often have you been able to stick to this plan? Would you say always, mostly, rarely, or never?

\section{Findings}

Table 1 reports the responses of 548 IMW to the financial literacy questions. The table surmises a low level of correctness indicating a low level of financial literacy of the ex-IMW. It shows that $35.22 \%$ of ex-IMW correctly answered the interest rate questions. This is surprising considering those questions are relatively easy.

Respondents were even less accurate regarding the inflation question, with 26.72 percent answering correctly. Only $34.41 \%$ of the respondents understood that holding a single basket implies a riskier investment than five baskets of eggs.

The question about riskier investment elicited the most "Don't Know" (DK) replies, comprising $29.96 \%$ of the respondents. The interest question elicited $19.43 \%$ of DKs, while the inflation question did $27.94 \%$. In terms of incorrect answers, most of the respondents had wrong answers to the interest rate question with $43.32 \%$ of the responses. There were $42.51 \%$ of responses answered incorrectly for the inflation question, and $31.98 \%$ of responses answered incorrectly for the riskier investment question. Having such a large proportion of incorrect answers and DKs, this research concludes that most of the IMW are financially illiterate. 


\begin{tabular}{|l|c|c|c|c|}
\hline & \multicolumn{4}{|c|}{ Responses } \\
\hline & Correct & Incorrect & Don't Know & Refuse \\
\hline Interest rate & $30.22 \%$ & $43.32 \%$ & $24.43 \%$ & $2.02 \%$ \\
\hline Inflation & $21.72 \%$ & $42.51 \%$ & $32.94 \%$ & $2.83 \%$ \\
\hline Risk diversification & $29.41 \%$ & $31.98 \%$ & $34.96 \%$ & $3.64 \%$ \\
\hline
\end{tabular}

Source: Authors' own calculation

This research divides the type of financial planning into three categories: Simple Planner, Serious Planner, and Committed Planner. This categorization is based on prior research such as Lusardi and Mitchell [2007a], van Rooij et al. [2011], and van Rooij et al. [2012]. If the respondent answered "Yes" to the first question ("Have you ever tried to figure out how much your household would need to save for retirement?") but answered "No" to the second question ("Have you developed a plan for retirement saving?"), he/she is called a "Simple Planner". There were $61.9 \%$ of respondents indicating that they had ever attempted to make a savings calculation. This is in line with prior research such as Lusardi and Mitchell [2007a] and van Rooij et al. [2011], where most people were actually categorized in this group.

The second group is the "Serious Planner". If a respondent answered "Yes" to the first question, and "Yes" or "More or Less" to the second question, and "Rarely" to the third question ("How often have you been able to stick to your financial planning?"), he/she was categorized in this group. This research found that there were $35.3 \%$ of respondent who fell in this group. The last group is the "Committed Planner". If the respondent answered "Mostly" to the third question, he/she fell in this group. There were only around $2 \%$ of respondents who were committed planners.

This research divides further the financial literacy into three groups, and links it with ex-IMWs' asset ownership. Firstly, there is a group called "Semi Financially Literate", containing those who only answered 1 or 2 questions correctly. There is also a group called "Financially Literate", containing those who answered 3 questions correctly. Meanwhile, those who answered all the 3 questions incorrectly are classified as "Illiterate".

Panel A portrays the mapping of the relationship between asset ownership and financial literacy. In terms of car ownership, there were $58.06 \%$ of respondents who have a car and are financially literate, while only $4.90 \%$ of respondents who do not have car and are financially literate. The rest is those who have a car on instalments and are semifinancially literate. This implies that if IMWs have a good level of financial literacy, they can own a car.

In terms of motorcycle ownership, $50 \%$ of those who owned a motorcycle were actually financially literate. There were $41.28 \%$ of ex-IMWs who have motorcycle credit, and $42.59 \%$ with no motorcycle are still in the group of financially literate. This is interesting because even though they do not have a motorcycle, they are financially literate. The prestige or pride of owning a car or an asset other than a motorcycle is the most likely explanation for this. 
Panel 1 | Descriptive analysis of the IMWs' wellbeing

\begin{tabular}{|c|c|c|c|c|c|c|c|c|}
\hline \multirow{4}{*}{ 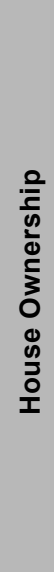 } & 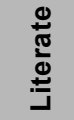 & $\begin{array}{l}\circ \\
\infty \\
0 \\
\stackrel{N}{ }\end{array}$ & $\frac{\stackrel{\circ}{N}}{\stackrel{+}{+}}$ & $\begin{array}{l}\stackrel{0}{0} \\
\stackrel{0}{0} \\
\stackrel{2}{0}\end{array}$ & & & & \\
\hline & 立离 & 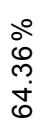 & $\begin{array}{l}\circ \\
0 \\
0 \\
\dot{m}\end{array}$ & $\begin{array}{l}\stackrel{\circ}{\circ} \\
\stackrel{\circ}{\sim} \\
\stackrel{2}{2}\end{array}$ & & & & \\
\hline & 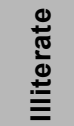 & $\begin{array}{l}\stackrel{\circ}{\circ} \\
\stackrel{\circ}{\leftarrow}\end{array}$ & $\begin{array}{l}\circ \\
\infty \\
\stackrel{0}{N}\end{array}$ & 官 & & & & \\
\hline & & 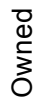 & $\begin{array}{l}\text { 荡 } \\
\text { d } \\
\end{array}$ & 을 & & & & \\
\hline \multirow{4}{*}{$\begin{array}{l}\frac{0}{E} \\
\frac{0}{0} \\
\frac{1}{0} \\
\frac{5}{3} \\
0 \\
\frac{0}{0} \\
\frac{0}{0} \\
\frac{0}{0} \\
\frac{0}{0}\end{array}$} & 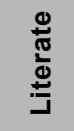 & $\begin{array}{l}\circ 0 \\
\circ \\
\circ \\
0\end{array}$ & $\begin{array}{l}\circ \\
\stackrel{0}{0} \\
\stackrel{0}{+}\end{array}$ & $\begin{array}{l}\stackrel{0}{\circ} \\
\hat{n} \\
\stackrel{0}{\circ}\end{array}$ & \multirow{4}{*}{ 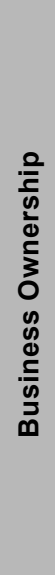 } & 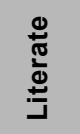 & $\begin{array}{l}\stackrel{0}{\circ} \\
\circ \\
\dot{0}\end{array}$ & $\begin{array}{l}\circ \\
\infty \\
\infty \\
1 \\
10\end{array}$ \\
\hline & 㐫离 & $\begin{array}{l}\stackrel{0}{\circ} \\
\text { } \\
\text { ळे }\end{array}$ & $\frac{0}{\tilde{\sigma}}$ & 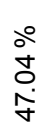 & & 立 & $\begin{array}{l}\stackrel{0}{\circ} \\
\circ \\
\circ \\
\stackrel{\circ}{N}\end{array}$ & $\begin{array}{l}\circ \\
\stackrel{+}{+} \\
0 \\
\sigma\end{array}$ \\
\hline & 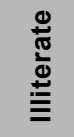 & $\begin{array}{l}\frac{0}{\pi} \\
\frac{1}{\sigma}\end{array}$ & $\begin{array}{l}\stackrel{\circ}{\circ} \\
\stackrel{\circ}{\dot{N}}\end{array}$ & 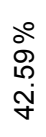 & & 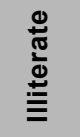 & $\begin{array}{l}\circ 0 \\
8 \\
\circ \\
\infty\end{array}$ & $\frac{\circ}{\stackrel{0}{\alpha}} \underset{\infty}{\infty}$ \\
\hline & & 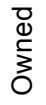 & $\begin{array}{l}\text { 蒙 } \\
\text { Uू }\end{array}$ & 을 & & & $\stackrel{\infty}{\nu}$ & 우 \\
\hline \multirow{4}{*}{ 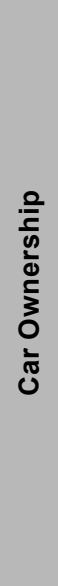 } & & $\begin{array}{l}\circ \\
0 \\
0 \\
\infty \\
\infty \\
\infty\end{array}$ & $\stackrel{\circ}{\stackrel{\circ}{N}}$ & $\begin{array}{l}\text { ஓे } \\
\text { هి } \\
\dot{\forall}\end{array}$ & \multirow{4}{*}{ 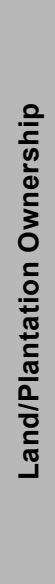 } & 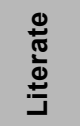 & 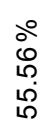 & $\begin{array}{l}0 \\
\text { గొ } \\
\infty \\
\infty\end{array}$ \\
\hline & 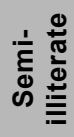 & $\begin{array}{l}\stackrel{0}{0} \\
\stackrel{0}{N} \\
\stackrel{m}{0}\end{array}$ & 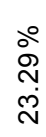 & 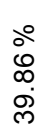 & & 㐫 & $\begin{array}{l}\text { o̊ } \\
0 \\
0 \\
0 \\
0\end{array}$ & $\begin{array}{l}\circ \\
\stackrel{0}{0} \\
\text { ஸे }\end{array}$ \\
\hline & 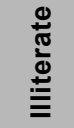 & $\begin{array}{l}\circ \\
\infty \\
0 \\
0\end{array}$ & $\begin{array}{l}\circ \\
\circ \\
0 \\
0 \\
0\end{array}$ & \begin{tabular}{l}
$\stackrel{0}{0}$ \\
\multirow{\Delta}{\Delta}{} \\
$i$ \\
$i$
\end{tabular} & & 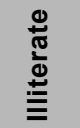 & $\begin{array}{l}\stackrel{0}{\circ} \\
\infty \\
\stackrel{9}{\square}\end{array}$ & $\stackrel{\circ}{\stackrel{0}{N}}$ \\
\hline & & 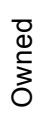 & 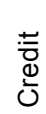 & z & & & $\stackrel{\infty}{\nu}$ & 은 \\
\hline
\end{tabular}

Source: Authors' own calculations 
Further, this research investigates house ownership. Before we describe the findings, it is noteworthy that most of the respondents stated that they had started paying house instalments before they went back to Indonesia. This is the same with those who owned land/plantation and/or a business. There were $33.68 \%$ of respondents from the financial literate group who owned a house. Interestingly, there were $54.36 \%$ of respondents from the semi-literate group who owned a house, indicating that they had put their investment and savings in a house rather than having other types of assets. This is tally with the house mortgages, where $64.17 \%$ of mortgage decisions were made by financially literate IMWs. There were $33.06 \%$ with house credit who are semi-financially literate. This table also shows that those with poor financial literacy have a poor pool of assets.

Preceding the discussion of the link between asset ownership and financial literacy, we define land/plantation ownership as assets that are used for agricultural such as paddy rice plantations, palm oil plantations, coffee plantations, vegetable plantations, or other plantations. The findings show that IMWs with land/plantation were dominated by the financially literate group $(55.6 \%)$. There were $30.56 \%$ and $13.89 \%$ who owned land/plantation in the semi-financially literate and illiterate group, respectively. Using this financial literacy theory, this research finds that illiterate IMWs dominated the group not owning land/plantation with $67.77 \%$. Interestingly, there was still a small number of financially literate who did not have land/plantation $(8.53 \%)$.

Additionally, this research also shows the association between business ownership and financial literacy. In the group of those who owned a business, there were $54 \%$ of respondents who were financially literate. There were also $28 \%$ and $18 \%$ of those who owned a business in the semi-financially literate and illiterate group, respectively. In the group of those who did not own a business, there was very a small fraction of the financially literate with $5.58 \%$. This group is dominated by financially illiterate people with a proportion of $78.17 \%$. In short, this research confirms that asset ownership is closely related to financial literacy.

Table 2 reports the results of a multivariate analysis that sheds some light on the importance of financial literacy and its relationship to financial planning. This research takes the types of financial planning as the dependent variables. Indeed, there are three types of financial planner in this research, which are the simple, serious ad committed planner. However, due to the limitation of data on the committed planner, this research only estimates the model by using two dependent variables, which are the simple planner and the serious planner. Because the dependent variable is categorical data, the estimate is run under the marginal effects of the Probit analysis.

We control the estimate by introducing gender to the equation. This is in line with previous research, stating that gender plays an important role in financial decision making. Table 2 indicates that gender plays a significant role in financial planning. This can be seen from the fact that the whole financial planning model has a $1 \%$ significance level due to the influence of gender. Then, this research categorized incorrect answers and Don't Know (DK) in the same group called the illiterate group. The results are as follows. 
Table 2 | Relationship between planning and literacy

\begin{tabular}{|l|l|l|l|l|l|l|}
\hline & \multicolumn{2}{|c|}{ Simple Planners (N=247) } & \multicolumn{2}{c|}{ Serious Planners (N=247) } \\
\hline & 1 & 2 & 3 & 1 & 2 & 3 \\
\hline $\begin{array}{l}\text { Correct on interest } \\
\text { rate }\end{array}$ & $0.060^{*}$ & & 0.044 & $0.061^{*}$ & & 0.041 \\
\hline & $(0.032)$ & & $(0.037)$ & $(0.037)$ & & $(0.034)$ \\
\hline Correct on inflation & $0.179^{* * *}$ & & $0.112^{* * *}$ & $0.168^{* * *}$ & & $0.107^{* * *}$ \\
\hline & $(0.034)$ & & $(0.037)$ & $(0.029)$ & & $(0.032)$ \\
\hline $\begin{array}{l}\text { Correct on risk } \\
\text { diversification }\end{array}$ & $0.135^{* *}$ & & $0.095^{* *}$ & $0.103^{* *}$ & & $0.081^{* *}$ \\
\hline & $(0.047)$ & & $(0.041)$ & $(0.044)$ & & $(0.041)$ \\
\hline Illiterate on inflation & & $-0.174^{* * *}$ & $-0.092^{*}$ & & $-0.192^{* * *}$ & $-0.095^{*}$ \\
\hline & & $(0.060)$ & $(0.052)$ & & $(0.061)$ & $(0.049)$ \\
\hline $\begin{array}{l}\text { Illiterate on interest } \\
\text { rate }\end{array}$ & & 0.023 & -0.005 & & 0.021 & -0.003 \\
\hline & & $(0.038)$ & $(0.079)$ & & $(0.079)$ & $(0.032)$ \\
\hline $\begin{array}{l}\text { Illiterate on riskier } \\
\text { investment }\end{array}$ & -0.068 & $-0.056^{* *}$ & & $-0.061^{* *}$ & $-0.051^{* *}$ \\
\hline & $(0.036)$ & $(0.022)$ & & $(0.026)$ & $(0.028)$ \\
\hline Gender & & $(0.072)$ & $(0.071)$ & $(0.061)$ & $(0.078)$ & $(0.061)$ \\
\hline Pseudo $\mathrm{R}^{2}$ & 0.033 & 0.077 & 0.058 & 0.061 & 0.102 \\
\hline
\end{tabular}

Note: The estimate model is run under Probit analysis. The figures are the coefficient with its marginal effects. Figures inside parentheses are the standard error. ${ }^{*},{ }^{* *}$, and ${ }^{* * *}$ indicate that the relationship is significant at the $10 \%, 5 \%$, and $1 \%$ level, respectively.

Source: Authors' own calculation

Firstly, the $\mathrm{R}^{2}$ of the model indicates that the models are robust enough, especially for categorical data based research. This research finds that financial literacy strongly and positively contributes to financial planning, and the results are statistically significant. For instance, the literacy on inflation contributes positively and statistically significantly at the $1 \%$ level to the simple planner and the serious planner. The same conclusion is found for the influence of riskier investment literacy on financial planning. However, the literacy on interest rate has been found not to be significant for financial planning. It seems that the interest rate is more general knowledge that might not affect a person's financial decisions. In addition, the illiteracy of financial knowledge also leads to a negative magnitude of financial planning, confirming the literacy theory. It shows that illiteracy on inflation contributes statistically significantly and negatively to financial planning. This implies that literacy on inflation might reduce the intention to keep to the financial planning. The illiteracy on 
riskier investment also shows a statistically significant effect on financial planning. The sign of the relationship is also negative, indicating an inverse relationship. However, the illiteracy on interest rate makes no significant contribution to financial planning; yet, the relationship is inverse ties; a support to financial literacy theory.

\section{Conclusion}

The objective of this research was to investigate the role of financial literacy in financial planning of Indonesian migrant workers (IMW). This includes the explanation of why ex-IMW are still living in poor conditions, and interestingly, the findings show that the ex-IMW have experienced a very low level of financial literacy. The lack of financial knowledge significantly affects their financial planning. Having poor financial planning makes IMWs live in poor conditions. This implies that the lack of financial knowledge is the base explanation of why IMWs still live in poor conditions after returning from their country of destination.

Additionally, this research also maps the association between financial literacy and ownership of assets. Interestingly, the findings of this research document that IMWs' ownership of assets is closely related to financial literacy.

This study is concerned with the ability of ex-IMWs to make sound saving decisions over a long period for a better future. Note that migrant workers in Indonesia contribute major income to the national budget (the largest after tax income). The results show that it is essential for IMW to have good financial literacy for doing good financial planning. This is a waking alarm for policymakers, especially the migrant workers' ministry, where it is important and urgent to develop and implement communication and education programmes on financial literacy for IMW. Furthermore, each Indonesian embassy abroad may assist the migrant workers' ministry in this matter by being the frontliner in educating IMW about financial knowledge and financial planning before returning to Indonesia. Finally, this research also contributes to the body of knowledge, especially the financial literacy theory, where it shows that financial literacy is suitable for explaining the economy of migrant workers. The argument for this research might on the unobservable variable or third factor that may affect the literacy or the direction of causality. We left this inquiry for future research.

\section{References}

ADAMS JR. R. H., 1991. The economic uses and impact of international remittances in rural

Egypt. Economic Development and Cultural Change, 39(4), 695-722.

DOI: http://dx.doi.org/10.1086/451904.

ALMENBERG, J. \& SÄVE-SÖDERBERGH, J., 2011. Financial literacy and retirement planning in Sweden. Journal of Pension Economics and Finance, 10(4), 585-598.

DOI: http://dx.doi.org/10.1017/S1474747211000497.

BEAL, D. J. \& DELPACHITRA, S. B., 2003. Financial literacy among Australian university students. Economic Papers, 22(1), 65-78.

DOI: http://dx.doi.org/10.1111/j.1759-3441.2003.tb00337.x.

BOOTH, A., 1999. Education and economic development in Southeast Asia: myths and realities. ASEAN Economic Bulletin, 16(3), 290-306. ISSN 02174472. 
BUCHER-KOENEN, T. \& LUSARDI, A., 2011. Financial literacy and retirement planning in Germany. Journal of Pension Economics \& Finance, 10(4), 565-584.

DOI: http://dx.doi.org/10.1017/S1474747211000485.

CARINO, D. R. \& ZIEMBA, W. T., 1998. Formulation of the Russell-Yasuda Kasai financial planning model. Operations Research, 46(4), 433-449. DOI: http://dx.doi.org/10.1287/opre.46.4.433.

DATTA, K., 2009. Risky migrants? Low-paid migrant workers coping with financial exclusion in London. European Urban and Regional Studies, 16(4), 331-344.

DOI: http://dx.doi.org/10.1177/0969776409340865.

DE HAAS, H., 2005. International migration, remittances and development: myths and facts. Third World Quarterly, 26(8), 1269-1284.

DOI: http://dx.doi.org/10.1080/01436590500336757.

DUSTMANN, C., 1997. Return migration, uncertainty and precautionary savings. Journal of Development Economics, 52(2), 295-316.

DOI: http://dx.doi.org/10.1016/S0304-3878(96)00450-6.

FORNERO, E. \& MONTICONE, C., 2011. Financial literacy and pension plan participation in Italy. Journal of Pension Economics and Finance, 10(4), 547-564.

DOI: http://dx.doi.org/10.1017/S1474747211000473.

GUISO, L. \& JAPPELLI, T., 2008. Financial literacy and portfolio diversification. ECO Working Papers. ISSN 1725-6704.

HAMILTON, W. F. \& MOSES, M. A., 1973. An optimization model for corporate financial planning. Operations Research, 21(3), 677-692. DOI: http://dx.doi.org/10.1287/opre.21.3.677.

HANNA, S. D. \& LINDAMOOD, S., 2010. Quantifying the economic benefits of personal financial planning. Financial Services Review, 19(2), 111-127. ISSN 1057-0810.

HASTINGS, J. S. \& TEJEDA-ASHTON, L., 2008. Financial literacy, information, and demand elasticity: survey and experimental evidence from Mexico [Working Paper No. 14538]. National Bureau of Economic Research. DOI: http://dx.doi.org/10.3386/w14538.

ISHI, A., 2003. Searching for home, wealth, pride, and 'class': Japanese Brazilians in the 'land of yen'. In Lesser, J. (ed.). Searching for home abroad: Japanese Brazilians and transnationalism, 75-102. ISBN 9780822331483.

JAPPELLI, T. \& PADULA, M., 2013. Investment in financial literacy and saving decisions. Journal of Banking \& Finance, 37(8), 2779-2792. DOI: http://dx.doi.org/10.1016/j.jbankfin.2013.03.019.

KLAPPER, L. \& PANOS, G. A., 2011. Financial literacy and retirement planning: the Russian case. Journal of Pension Economics \& Finance. 10(4), 599-618.

DOI: http://dx.doi.org/10.1017/S1474747211000503.

KUMAR, B., 1984. Planning, poverty and economic development. New Delhi: Deep and Deep Publications. ISBN 978-0391032576.

LIPSEY, R. E. \& SJÖHOLM, F., 2004. Foreign direct investment, education and wages in Indonesian manufacturing. Journal of Development Economics, 73(1), 415-422.

DOI: http://dx.doi.org/10.1016/j.jdeveco.2002.12.004.

LUSARDI, A. \& MITCHELL, O. S., 2007a. Baby boomer retirement security: the roles of planning, financial literacy, and housing wealth. Journal of Monetary Economics, 54(1), 205-224. DOI: http://dx.doi.org/10.1016/j.jmoneco.2006.12.001.

LUSARDI, A. \& MITCHELL, O. S., 2007b. Financial literacy and retirement preparedness: evidence and implications for financial education. Business Economics, 42(1), 35-44.

DOI: http://dx.doi.org/10.2145/20070104. 
LUSARDI, A. \& TUFANO, P., 2009. Debt literacy, financial experiences, and overindebtedness [Working Paper No. 14808]. National Bureau of Economic Research.

DOI: http://dx.doi.org/10.3386/w14808.

LUSARDI, A., MITCHELL, O. S. \& CURTO, V., 2010. Financial literacy among the young. Journal of Consumer Affairs, 44(2), 358-380. DOI: http://dx.doi.org/10.1111/j.1745-6606.2010.01173.x.

MCENEANEY, J. E., 2006. Agent-based literacy theory. Reading Research Quarterly, 41(3), 352-371. DOI: http://dx.doi.org/10.1598/RRQ.41.3.3.

MITCHELL, O. S., MOORE, J. \& PHILLIPS, J., 2000. Explaining retirement saving shortfalls. Forecasting Retirement Needs and Retirement Wealth, 68-94. ISBN 9780812235296.

PURI, S. \& RITZEMA, T., 1999. Migrant worker remittances, micro-finance and the informal economy: prospects and issues [Working Paper No. 21]. Geneva: ILO. ISBN 92-2-111783-9.

RAHARTO, A., 2007. Indonesian labour migration: issues and challenges. Migration and Integration in the Asia-Pacific Region, 9(2), 219-235. ISSN 1817-4574.

SEKITA, S., 2011. Financial literacy and retirement planning in Japan. Journal of Pension Economics and Finance, 10(4), 637-656. DOI: http://dx.doi.org/10.1017/S1474747211000527.

SERVON, L. J. \& KAESTNER, R., 2008. Consumer financial literacy and the impact of online banking on the financial behavior of lower-income bank customers. Journal of Consumer Affairs, 42(2), 271-305. DOI: http://dx.doi.org/10.1111/j.1745-6606.2008.00108.x.

SESHAN, G. \& YANG, D., 2012. Transnational household finance: a field experiment on the cross-border impacts of financial education for migrant workers. Qatar Foundation Annual Research Forum Proceedings. DOI: http://dx.doi.org/10.5339/qfarf.2012.AHO3.

TOTH, J., 1991. Pride, purdah, or paychecks: what maintains the gender division of labor in rural Egypt? International Journal of Middle East Studies, 23(2), 213-236.

DOI: http://dx.doi.org/10.1017/S0020743800056051.

TURNER, M., IMBARUDDIN, A. \& SUTIYONO, W., 2009. Human resource management: the forgotten dimension of decentralisation in Indonesia. Bulletin of Indonesian Economic Studies, 45(2), 231-249. DOI: http://dx.doi.org/10.1080/00074910903040336.

VAN ROOIJ, M. C., LUSARDI, A. \& ALESSIE, R. J., 2011. Financial literacy and retirement planning in the Netherlands. Journal of Economic Psychology, 32(4), 593-608.

DOI: http://dx.doi.org/10.1016/j.joep.2011.02.004.

VAN ROOIJ, M. C., LUSARDI, A. \& ALESSIE, R. J., 2012. Financial literacy, retirement planning and household wealth. The Economic Journal, 122(560), 449-478.

DOI: http://dx.doi.org/10.1111/j.1468-0297.2012.02501.x.

WEEKLEY, K., 2004. Saving pennies for the state. A new role for Filipino migrant workers? Journal of Contemporary Asia, 34(3), 349-363.

DOI: http://dx.doi.org/10.1080/00472330480000151.

ZARATE-HOYOS, G. A., 2004. Consumption and remittances in migrant households: toward a productive use of remittances. Contemporary Economic Policy, 22(4), 555-565.

DOI: http://dx.doi.org/10.1093/cep/byh04. 